\title{
Oldowan Scavengers Vs. Acheulian Hunters: What Does the Faunal Record Say?
}

\author{
Bienvenido Martínez-Navarro* \\ ICREA at the Catalan Institute of Human Paleoecology and Social Evolution-IPHES, Rovira i Virgili University (URV), 43007 Tarragona, Spain
}

Submission: August 15, 2018; Published: August 22, 2018

*Corresponding author: Bienvenido Martínez-Navarro, ICREA at the Catalan Institute of Human Paleoecology and Social Evolution-IPHES, Rovira i Virgili University (URV), 43007 Tarragona, Spain, Email: Bienvenido.martinez@icrea.cat

Keywords: Oldowan; Acheulian; Scavengers; Hunters; Late Pliocene; Early Pleistocene; Middle Pleistocene; Europe; Asia; Africa; Archaeology; Omnivorous; Artifacts; Pebbles; Mammals; Buffalo; Hippo; Rhino; Horse; Elephant

\section{Opinion}

Between 3 and 2 million years ago, our eastern African ancestors became omnivorous. A biped primate with mostly vegetarian eating strategy changed and started to eat animal food, meat and fat coming from the carcasses of large mammals, developing at the beginning a scavenging behavior. This was only possible thanks to the development of one extrasomatic evolution, the cultural technology making lithic artifacts, flakes to cut and dismember the carcasses and percussion tools to break the bones and extract the marrow content. These earliest lithics were very primitive and rudimentary, dominated by pebbles, cores and flakes, corresponding to the named Oldowan or Mode 1.

This technical innovation was the key for human evolution, but also the key for human dispersal out of Africa. During the latest Pliocene and Early Pleistocene humans increased their carnivore behavior, ingesting more quantity of meat and fat, and transforming their physiology making their digestive system shorter thanks to the ingestion of better quality and more energetic food, and transferring the surplus energy to the feeding and growth of the brain [1].

Herbivores are specialized to eat a kind of plants that directly depends on the climate. Then, these animals are normally conditioned by the climate where the plants they eat grow, which is related to the latitude. For this reason, herbivores normally have a longitudinal distribution on the continents. Carnivores, on the contrary, eat meat and it doesn't matter what is the animal where it is coming from. Meat is meat, and there are no big differences on energy if it is from a buffalo, a hippo, a rhino, a horse, an elephant or any other species. Then, the area of distribution of carnivore species is not restricted by climate, and now we can see that leopards are dispersed by an area from South Africa to most of Asia, and they were present in Europe until the end of the Pleistocene. It was also the same for lions and spotted hyenas.

Once humans have developed their abilities to find and eat meat and fat, their possibilities for dispersal increased exponentially and, around 2 million-years-ago, humans were able to disperse out of Africa and colonize the middle latitudes of Eurasia, as it is recorded at the site of Dmanisi in the Caucasus $[2,3]$, dated 1.800 .000 years old. This first dispersal was done by hominins carrying with them the rudimentary Oldowan tools.

Oldowan tools persisted in Eurasia for more than 1 million years, until the base of the Middle Pleistocene but, in Africa something very important happened, a new technology emerged at around 1.700.000-1.600.000 years ago. It is the Acheulian or Mode 2, where the concept of symmetry is developed, and the most typical elements of this culture are the handaxes.

The Acheulian hominins developed the technology and few hundred thousand years later this culture was common around most of the African continent but, although there are few findings of primitive Acheulian in the Levantine Corridor, like 'Ubeidiya in Israel [4], dated ca. 1.200.000-1.600.000 years old, and south Asia, like Attirampakkam India, dated ca. 1.500 .000 years old [5], developed Acheulian trigged one million years to colonize and be common in the Eurasian continent, until the base of the Middle Pleistocene, around 800.000-600.000 years ago.

Following this reasoning, African Acheulian people were in practically no contact with Eurasian Oldowan people during practically 1 million years, for 1.700 .000 years ago until the beginning of the Middle Pleistocene, 800.000 years ago. In many cases, hominins and lithic artifacts are found in the same levels together with large mammal's fossil bones which, often, have cut and/or broken marks that have been provoked by the lithic artifacts to cut the meat and to extract the fat from the bones. 
This is the direct evidence that our ancestors were eating the carcasses of these animals.

\section{What Does the Record of Large Mammals Say to Understand the Hunting or Scavenging Human Behavior?}

In paleontology and archaeology, it is always important what is recorded in the fossil assemblages. These are the data that help scientists to interpret and build up the hypothesis to understand how the site formation process was and, sometimes, how was the specific behavior of fossil humans and other species. Because of this, the excavation and all the analytic studies must be done following a methodological work. In the base of these archaeological and paleontological data, archaeologist have discussed for long decades what was the hunter or scavenging behavior of humans since our ancestors started to eat animal resources.

My experience, as a senior researcher, working for a long time in different Early and Middle Pleistocene archaeopaleontological sites around southern Europe, the Caucasus, the Levantine Corridor, northern and eastern Africa, suggest that always findings are important but, sometimes, we must analyze what is not recorded, what is not present in the fossil assemblages, and then, try to explain why?

Because of this, I always have been surprised to see how different the faunal record in Oldowan assemblages is, where the presence of carnivores is normally very important in number of species but also in specimens. Interesting examples of this are, among others, those from Fuente Nueva 3 and Barranco León in Orce, southern Spain, dated ca. 1.400 .000 years ago, composed by a very good record of carnivore species [Ursus etruscus, Lycaon lyconoides, Canis mosbachensis, vulpes cf. praeglacialis, Pachycrocuta brevirostris, Megantereon whitei, cf. Homotherium sp., Lynx sp., Meles meles, Pannonictis cf. nestii, Mustelidae indet. (small size)] [6], or that from Vallonnet in southern France, dated 1.100.000 years ago (Ursus deningeri, Xenocyon lycaonoides, Canis mosbachensis, Alopex praeglacialis, Pachycrocuta brevirostris, Homotherium crenatidens, Acinonyx pardinensis, Panthera gombaszoegensis, Panthera pardus, Lynx spelaeus, Felis silvestris, and Meles meles) [7]. This good record of carnivore remains is also normal in localities with primitive Acheulian artifacts such as 'Ubeidiya in Israel (Ursus etruscus Canis mosbachensis, Lycaon lycaonoides, Vulpes cf. V. praeglacialis, Megantereon cf. M. whitei, Panthera cf. P. gombaszoegensis, Lynx sp., Felis sp., and Crocuta crocuta) [8]. But the presence of carnivores is scarce, very scarce or null, although the record of ungulates is very good, when the developed Acheulian assemblages start to be dominant in Africa and later in Eurasia. This is the case in Buia, Eritrea, dated ca. 1.000.000 years old [9], Tighenif (formerly Ternifine) in Algeria, dated ca. 1.000.000 years old [10]; Wadi Sarrat in Tunisia, dated ca. 700.000 years old [11], Gesher Benot Ya'aqov in Israel, dated ca. 800.000-700.000 years old [12], or those from the Middle Pleistocene of Europe, such as the Solana del Zamborino, in southern Spain, dated ca. 300.000-480.000 years old [13], or in the levels C1a and $\mathrm{b}$ from Terra Amata in southern France, dated ca. 380.000-400.000 years old [14].

\section{How can we Interpret the Faunal Record of These Oldowan and Acheulian Assemblages?}

Maybe it is not totally clear, but the most feasible interpretation is that Oldowan humans were part of the faunal assemblage with no control on the ecosystem, with no hunting habilities, cohabiting and competing with other carnivores, especially with large hyenas, for the carrion. Because of this, carnivores are normally well represented in these archaeopaleontological sites. This continues during the first primitive Acheulian assemblages but, when hominins developed the Acheulian culture something very important changed in their behavior. Humans became hunters and didn't need to be scavengers taking advantage on the preys hunted by other carnivores. Acheulian hominins controlled the ecosystems and the carnivores were expulsed from their areas of influence.

\section{Acknowledgement}

This research has been supported by the Spanish Ministry of Science (grant CGL2016-80975-P), the Generalitat of Catalonia (grant GENCAT 2017SGR 859), and the Palarq Foundation.

\section{References}

1. Aiello LC, Wheeler P (1995) The Expensive-Tissue Hypothesis: The Brain and the Digestive System in Human and Primate Evolution. Current Anthropology 36 (2): 199-221.

2. Lordkipanidze D, Jashashvili T, Vekua A, de Leon MSP, Zollikofer CPE, et al. (2007) Postcranial evidence from early Homo from Dmanisi, Georgia. Nature 449: 305 - 310.

3. Lordkipanidze D, Ponce de León MS, Margvelashvili A, Rak Y, Rightmire $\mathrm{GPh}$, et al. (2013) Complete skull from Dmanisi, Georgia, reveals evolutionary biology of early Homo. Science 342: 326-331.

4. Bar-Yosef O, Goren-Inbar N (1993) The Lithic Assemblages of the Site of Ubeidiya, Jordan Valley. Qedem, Jerusalem, Israel, p. 34.

5. Pappu S, Gunnell Y, Akhilesh K, Braucher R, Taieb M, et al. (2011) Early Pleistocene Presence of Acheulian Hominins in South India. Science 331: 1596-1599.

6. Martínez-Navarro B, Palmqvist P, Madurell J, Ros-Montoya S, Espigares MP, et al. (2010) La fauna de grandes mamíferos de Fuente Nueva-3 y Barranco León-5: estado de la cuestión. Ocupaciones humanas en el Pleistoceno inferior y medio de la cuenca de Guadix-Baza. Consejería de Cultura, Junta de Andalucía, Arqueología Monografías. pp. 197-236.

7. Moullé PE, Lacombat F, Echassoux A (2006) Contribution of the large mammals of Vallonnet cave (Roquebrune-Cap-Martin, AlpesMaritimes, France) to the knowledge of biochronological frame of the second half of the Lower Pleistocene in Europe. L'Anthropologie 110: 837-849.

8. Martínez-Navarro B, Belmaker M, Bar-Yosef O (2009) The large carnivores from Ubeidiya (early Pleistocene, Israel): biochronological and biogeographical implications. J Hum Evol 56: 514-524.

9. Martínez-Navarro B, Rook L, Segid A, Yosief D, Ferretti MP, et al. (2004) The Large Fossil Mammals from Buya (Eritrea): Systematics, Biochronology and Paleoenvironments. Rivista Italiana di Paleontologia e Stratigrafia 110: 61- 88. 
10. Geraads D, Hublin JJ, Jaeger JJ, Tong H, Sen S, et al. (1986) The Pleistocene Hominid Site of Ternifine. Algeria: New Results on the Environment, Age, and Human Industries. Quat Res 25: 380-386.

11. Martínez Navarro B, Karoui-Yaakoub N, Oms O, Amri L, López-García JM, et al. (2014) The early Middle Pleistocene archaeopaleontological site of Wadi Sarrat (Tunisia) and the earliest record of Bos primigenius. Quat Sci Rev 90: 37 - 46.

12. Martínez Navarro B, Rabinovich R (2011) The fossil Bovidae (Artiodactyla, Mammalia) from Gesher Benot Ya'akov, Israel: out of
Africa during the Early-Middle Pleistocene transition. J Hum Evol 60 375 - 386.

13. Álvarez-Posada C, Parés JM, Sala R, Viseras C, Pla-Pueyo S (2017) New magnetostratigraphic evidence for the age of Acheulean tools at the archaeo-palaeontological site Solana del Zamborino. Scientific Reports 7: 13495 .

14. De Lumley H (2016) Terra Amata (Nice, Alpes-Maritimes, France). Comportement et mode de vie des chasseurs acheuléens de Terra Amata (Eds.), CNRS Editions, Tome V, USA.

\section{Your next submission with Juniper Publishers will reach you the below assets}

- Quality Editorial service

- Swift Peer Review

- Reprints availability

- E-prints Service

- Manuscript Podcast for convenient understanding

- Global attainment for your research

- Manuscript accessibility in different formats

( Pdf, E-pub, Full Text, Audio)

- Unceasing customer service

Track the below URL for one-step submission https://juniperpublishers.com/online-submission.php 